\title{
PENGAWASAN TERHADAP PERATURAN KEPALA DAERAH
}

\author{
E. Prajwalita Widiati dan Haidar Adam \\ Fakultas Hukum Universitas Airlangga \\ prajwalita.widiati@fh.unair.ac.id, mazhaidar@yahoo.com
}

\begin{abstract}
Decentralisation puts weigh in the dynamic of local government. As consequences of decentralization, local governments are entitled to enact local regulation in order to serve public services in the daily basis. Local regulation as the product of the Mayor of course does not stand alone. It is part of national legislative system which lay at the low tier of the hierarchy of laws. It should be work effectively and harmoniously with the system. By analyzing the nature of decentralization and the function of local legislation, it is essential to establish a good review mechanism for this legislative product. Different mechanism results in different consequences to the regulation. This article has analysed three mechanisms both preventive and represive; executive review which is done by the Governor and National Government; judicial review which is done by the Court and even political review which is exercised by the local representatives who act as balancing power to the local executive.
\end{abstract}

Keywords: Peraturan Kepala Daerah, Executive Review, Judicial Review, Political Review

\begin{abstract}
Abstrak
Desentralisasi menempati kedudukan tersendiri dalam dinamika lokal pemerintahan daerah. Sebagai konsekuensi desentralisasi, pemerintah daerah berhak untuk memberlakukan peraturan daerah untuk melayani pelayanan publik di setiap hari. Peraturan daerah sebagai produk dari Walikota tentu saja tidak berdiri sendiri. Ini adalah bagian dari sistem legislatif nasional yang terletak di tingkat yang rendah dari hirarki hukum. Ini harus bekerja secara efektif dan harmonis dengan sistem. Dengan menganalisis sifat desentralisasi dan fungsi legislasi lokal, adalah penting untuk membangun mekanisme peninjauan baik untuk produk legislatif ini. Hasil mekanisme yang berbeda dalam konsekuensi yang berbeda dengan peraturan. Artikel ini telah menganalisis tiga mekanisme pencegahan dan represif, tinjauan eksekutif yang dilakukan oleh Gubernur dan Pemerintah Nasional; judicial review yang dilakukan oleh Pengadilan dan bahkan tinjauan politik yang dilakukan oleh perwakilan lokal yang bertindak sebagai penyeimbang kekuatan untuk lokal eksekutif.
\end{abstract}

Kata Kunci: Peraturan Kepala Daerah, tinjauan eksekutif, tinjauan yudisiil, tinjauan politis. 


\section{Pendahuluan}

Di tengah dinamika demokrasi di era otonomi daerah, rupanya regulasi daerah adalah yang paling banyak dipersoalkan setelah sengketa PILKADA. Bagaimana tidak? Undang-Undang Dasar Negara Republik Indonesia 1945 (UUD NRI 1945) melalui pasal 18 ayat (6) mengatur bahwa dalam rangka pelaksanaan otonomi dan tugas pembantuan, Pemerintahan Daerah berhak menetapkan peraturan daerah dan peraturan lainnya. Sehingga dapat dibayangkan, berapa banyak produk peraturan daerah yang lahir di Indonesia dalam satu tahun dengan jumlah propinsi yang 33 dan kota/ kabupaten sejumlah 265.

Penerapan otonomi daerah di Indonesia ditujukan untuk mendorong terwujudnya dua hal, yang pertama adalah tercapainya kesejahteraan masyarakat yang merata dan yang kedua adalah mempercepat demokratisasi di daerah ${ }^{1}$. Disinilah peran regulasi daerah, ia merupakan alat yang dapat digunakan dalam rangka membuat kedua visi ini menjadi nyata. Seiring terjadinya banjir produk hukum daerah akibat luas wilayah Indonesia, kajian tentang pengawasan yang efektif terhadap produk hukum di daerah mulai mengemuka. Namun, kajian yang selamaini dibahas hampir seluruhnyatentang Peraturan Daerah. Sudah barang tentu jika pembentukan Peraturan Daerah lebih sering menjadi sorotan karena Peraturan tersebut sesungguhnya merupakan wujud atau produk nyata dinamika demokrasi di

${ }^{1}$ Penjelasan Umum Undang-Undang Nomor 32 Tahun 2004 tentang Pemerintahan Daerah, LN tahun 2004 No. 12, TLN No. 4437. daerah, dimana Peraturan Daerah dibentuk oleh dua lembaga yang dipilih masyarakat secara langsung melalui pemilukada.

Di sisi yang lain, agaknya penting juga adanya riset yang mengangkat tema Peraturan Kepala Daerah, karena dalam miniatur pemerintahan di tingkat daerah, maka Peraturan Kepala Daerah merupakan Peraturan Pemerintah-nya Kota/Kabupaten, ia adalah turunan dari Perda (Peraturan Daerah). Maka, sebenarnya Peraturan Kepala Daerah merupakan sendi dalam tatanan regulasi daerah ${ }^{2}$.

Peraturan Kepala Daerah memiliki potensi permasalahan takkalah rumitnya dengan Peraturan Daerah. Sebagai contoh adalah kasus yang menimpa Wali Kota Surabaya Tri Rismaharini oleh Pansus Hak Angket DPRD terkait terbitnya Peraturan Walikota Surabaya Nomor 56 dan 57 Tahun 2010 tentang kenaikan pajak reklame. Beberapa pihak yang merasa dirugikan dengan keberlakuan Peraturan Walikota ini mengeluhkan permasalahannya pada DPRD. Dalam kasus ini, DPRD Kota Surabaya, atas dasar kewenangan pengawasan yang dimilikinya, meminta Walikota memberikan penjelasan atas keberlakuan Peraturan Walikota tersebut. Dalam perkembangan investigasi kasus tersebut sempat terdapat wacana pemakzulan Walikota ${ }^{3}$. Walaupun akhirnya Walikota Surabaya tidak sampai dimakzulkan, namun apakah mungkin atas kebijakan dalam Peraturan Kepala Daerah

\footnotetext{
${ }^{2}$ Undang-Undang Nomor 32 Tahun 2004 tentang Pemerintahan Daerah, LN tahun 2004 No. 12, TLN No. 4437 Pasal 146 ayat (1).

${ }^{3}$ Berita diakses di Tempointeraktif.com pada 1 Februari 2011.
} 
dapat berakibatpemakzulan Walikota/Bupati atau Gubernur? Bagaimanakah sebenarnya mekanisme pengawasan terhadap Peraturan Kepala Daerah?

Dalam rangka pengawasan pemerintahan daerah di tingkat Kabupaten dan Walikota, Gubernur memiliki peranan penting. Menteri Dalam Negeri Gamawan Fauzi menegaskan gubernur sebagai perwakilan tertinggi presiden di provinsi memiliki wewenang untuk memberi teguran dan sanksi bagi bupati maupun pejabat instansi vertikal. Hal tersebut sebagai implementasi Peraturan Pemerintah (PP) Nomor 19 Tahun 2010 yang mengatur kewenangan gubernur sebagai perwakilan tertinggi pemerintah pusat di daerah. Walaupun di sisi lain Mendagri mengatakan aturan baru ini masih terdapat kelemahan karena belum menjabarkan secara rinci sanksi tersebut termasuk cakupan wewenang gubernur dalam garis komando koordinasi di level provinsi hingga kabupaten/ kota. ${ }^{4}$

Penelitian ini ingin menelaah posisi Peraturan Kepala Daerah baik Gubernur maupun Walikota dan Bupati yang dibuat dalam konteks delegasi dari peraturan poerundang-undangan yang lebih tinggi maupun dalam konteks aturan kebijakan (beleidsregel). Penelitian ini juga berusaha untuk menganalisa pengawasan terhadap Peraturan Kepala Daerah ini antara kewenangan yang dimiliki oleh MA dengan Pemerintah Pusat. Tulisan ini ingin mengulas tentang kedudukan Peraturan Kepala Daerah dalam kaitannya dengan

${ }^{4}$ Yuhardin, Gubernur Bisa Cabut Kebijakan BupatiWalikota, http://www.scriptintermedia.com/, diakses tgl 10 Pebruari 2011. pelaksanaan pemerintahan di daerah serta mekanisme pengawasan terhadap Peraturan Kepala Daerah serta akibat hukum terhadap pengawasan tersebut.

\section{Kedudukan Peraturan Kepala Daerah}

Peraturan Kepala Daerah dalam hierarkhi peraturan perundang-undangan dapat ditafsirkan melalui Pasal 8 ayat (1) dan (2) Undang-undang Nomor 12 Tahun 2011 tentang Pembentukan Peraturan Perundang-undangan. Bahwa peraturan perundang-undangan selain yang disebutkan dalam hierarkhi masih dimungkinkan keberadaannya sepanjang diperintahkan oleh Peraturan yang lebih tinggi. Produk perundang-undangan inilah yang masuk dalam lingkup delegated legislation/ secondary legislation ${ }^{5}$.

Fungsi pertama Peraturan Kepala Daerah adalah merinci ketentuan dalam Peraturan Daerah yang sangat umum, untuk memberikan pedoman prosedural ${ }^{6}$. Dengan peran yang demikian, maka ia adalah peraturan yang subordinate terhadap Peraturan Daerah (Perda), sehingga isinya tidak boleh bertentangan dengan peraturan di atasnya atau dengan kata lain Perkada adalah salah satu bentuk produk delegated legislation. Sebagai delegated legislation, maka area pertama yang disentuh oleh peraturan ini, adalah sebagai Peraturan Perundang-undangan.

Berikutnya, dalam konteks pelaksanaan

\footnotetext{
5 Jimly Asshiddiqie, Perihal Undang-Undang, Sekretariat Jenderal Mahkamah Konstitusi, 2005, h. 105.

${ }^{6}$ Undang-Undang Nomor 32 Tahun 2004 tentang Pemerintahan Daerah, LN tahun 2004 No. 12, TLN No. 4437 Pasal 146 ayat (1).
} 
pemerintahan, Kepala Daerah menjalankan fungsi pelayanan publik dimana untuk melaksanakan kewenangannya tersebut Gubernur/Walikota/Bupati membutuhkan perangkat hukum yang bersifat memaksa. Kewenangan membentuk produk hukum melekat secara inheren pada Pemerintah bersamaan dalam kewajiban mengatur dan mengurus kepentingan umum ${ }^{7}$. Tiga alasan yang melandasi adanya kewenangan ini, menurut Indroharto adalah; luasnya lingkup hukum administrasi sehingga tidak mungkin seluruhnya dapat dituangkan dalam undangundang formil; lalu berikutnya adalah bahwa dinamika pelayanan publik yang sangat cepat tidak mungkin diikuti oleh perubahan undang-undang bahkan seringkali publik menuntut tindakan administrasi yang cepat dan tanggap (emergency legislation); alasan terakhir adalah bahwa pengaturan lebih lanjut selalu berkaitan dengan penilainpenilaian dari segi teknis yang mendetail dan terukur. Pemberian kewenangan legislasi kepada administrasi ini kemudian lebih sering dikatakan sebagai "regulasi", karena ada unsur "kebijakan" di dalamnya, "to regulate/membuat kebijaksanaan". Berbeda dengan istilah "legislasi” yang lebih menunjuk pada pembuatnya "legislator/law maker" yang berarti lembaga perwakilan/ mencipta undang-undang.

Sebagai produk hukum yang dapat dikeluarkan oleh Kepala Daerah dalam rangka menjalankan tugas pelayanan publik,

${ }^{7}$ Ridwan, Tiga Dimensi Hukum Administrasi dan Peradilan Administrasi, FH-UII, Press, Yogyakarta2009, hlm.63-64. Indrati, Maria Farida, Ilmu Perundangundangan 1, Yogyakarta, Kanisius, 2007. h.43 maka telah jelas bahwa posisi Peraturan Kepala Daerah disamping sebagai Peraturan Perundang-undangan, ia juga merupakan Peraturan Kebijakan. Dua posisi berbeda Peraturan Kepala Daerah sebagai Peraturan Perundang-undangan dan Peraturan Kebijaksanaan ini tentu berimplikasi pada konsekuensi hukum yang berbeda pula.

Dalam tinjauan pustaka pada Bab II telah disinggung tentang Peraturan Kepala Daerah yang lahir atas delegasi peraturan di atasnya dan Peraturan Kepala Daerah yang lahir sebagai exit clause. Kajian yang telah ada mengungkapkan bahwa perbedaan ratio legis pembentukan Peraturan Kepala Daerah ini membawa konsekuensi pada perbedaan batu uji.

Kedudukan Peraturan Kepala Daerah sebagai peraturan perundang-undangan agaknya non-debatable. Penjelasan mengenai hal ini juga telah dirinci pada bab tinjauan pustaka sehingga pembahasan mengenai posisi Peraturan Kepala Daerah ini rupanya tanpa banyak pengulangan kiranya perlu langsung diarahkan pada variable yang lain yakni Peraturan Kepala Daerah sebagai Peraturan Kebijakan.

Secara umum, peraturan kebijakan dapat didefinisikan sebagai peraturan umum yang dikeluarkan oleh pemerintah (dalam pengertian eksekutif) berkaitan dengan tugas dan tanggung jawab yang melekat pada wewenang yang dimilikinya. Sehingga, dasar hukum peraturan kebijakan bukanlah peraturan perundang-undangan melainkan disandarkan pada wewenang pemerintahan tersebut. Peraturan Kebijakan 
ini mempunyai 4 elemen; pertama adalah peraturan umum (mengikat intern dan ekstern); kedua, berkenaan dengan pelaksanaan kewenangan pemerintahan terhadap warga Negara; ketiga, ditetapkan oleh suatu instansi pemerintahan yang berwenang untuk mengambil tindakan yang dimaksud; keempat, peraturan kebijakan harus dilaksanakan sesuai Asas-asas umum pemerintahan yang baik.

Melihat posisi peraturan kebijakan yang "tanpa cantolan" peraturan perundangundangan yang lebih tinggi, pertanyaan yang muncul kemudian adalah dalam konteks bagaimanakah peraturan kebijakan dapat dikeluarkan. Acap kali dalam praktek pemerintahan terjadi kesenjangan antara legalitas dan realitas, padahal dinamika pelayanan publik mengharuskan tindakan yang cepat, masyarakat membutuhkan solusi permasalahannya dengan segera tanpa menunggu ada atau tidak aturan hukumnya. Dalam rangka mengatasi kesenjangan ini diberikanlah freies Ermessen yang inheren dengan wewenang pemerintahan sebagai emergency exit. freies Ermessen ini digunakan ketika; pertama, kondisi darurat yang tidak memungkinkan untuk menerapkan ketentuan tertulis; kedua, tidak ada atau belum ada peraturan yang mengaturnya; ketiga, sudahada peraturannya namun normanya menimbulkan bias.

Bagir Manan menyebutkan ciriciri peraturan kebijakan sebagai berikut ; Peraturan kebijakan bukan merupakan peraturan perundang-undangan ${ }^{8}$; asas- asas pembatasan dan pengujian terhadap peraturan perundang-undangan tidak dapat diberlakukan pada peraturan kebijakan; Peraturan kebijakan tidak dapat diuji secara wetmatigheid, karena memang tidak ada dasar peraturan perundang-undangan untuk membuat keputusan peraturan kebijakan tersebut; Peraturan kebijakan dibuat berdasarkan freies Ermessen dan ketiadaan wewenang administrasi bersangkutan membuat peraturan perundang-undangan; Pengujian terhadap peraturan kebijakan lebih diserahkan pada doelmatigheid dan karena itu batu ujinya adalah asas-asas umum pemerintahan yang layak; Dalam praktek diberi format dalam berbagai bentuk dan jenis aturan, yakni keputusan, instruksi, surat edaran, pengumuman dan lain-lain, bahkan dapat dijumpai dalam bentuk peraturan. Tabel berikut ini menggambarkan persamaan dan perbedaan antara karakteristik peraturan perundangundangan dan peraturan kebijakan.

Tabel 1.

\begin{tabular}{|c|c|}
\hline \multicolumn{2}{|c|}{ ATURAN KEBIJAKAN } \\
\hline Persamaan & Perbedaan \\
\hline Aturan yang berlaku umum & $\begin{array}{l}\text { Pembentukan perundang- } \\
\text { undangan merupakan } \\
\text { fungsi Negara. }\end{array}$ \\
\hline $\begin{array}{l}\text { Peraturan yang berlaku "ke } \\
\text { luar" }\end{array}$ & $\begin{array}{l}\text { Fungsi pembentukan } \\
\text { peraturan kebijakan ada } \\
\text { pada pemerintah dalam } \\
\text { arti sempit (eksekutif). }\end{array}$ \\
\hline $\begin{array}{l}\text { Kewenangan pengaturan } \\
\text { yang bersifat umum/publik }\end{array}$ & $\begin{array}{l}\text { Materi muatan peraturan } \\
\text { perundang-undangan } \\
\text { berbeda dengan materi } \\
\text { muatan peraturan } \\
\text { kebijakan. }\end{array}$ \\
\hline
\end{tabular}

\footnotetext{
${ }^{8}$ Ridwan, op.cit., h.65.
} 


\begin{tabular}{|l|lr|}
\hline- & Sanksi & peraturan \\
kebijakan & hanya & dapat \\
mencantumkan & sanksi \\
administratif & sedangkan \\
peraturan & perundang- \\
undangan & yang \\
pembentukannya & melalui \\
persetujuan & wakil & rakyat \\
dapat saja & memuat & sanksi \\
yang & membatasi & hak-hak \\
warga Negara. & \\
\hline
\end{tabular}

Lingkup materi muatan peraturan kebijakan berhubungan dengan kewenangan membentuk keputusan-keputusan dalam arti beschikkingen, kewenangan bertindak dalam bidang hukum privat dan kewenangan membuat rencana-rencana yang melekat pada lembaga pemerintahan.

\section{Executive Review oleh Pejabat yang lebih tinggi}

Konsekuensi logis dalam Negara kesatuan adalah kewenangan penuh PemerintahPusatuntukcampurtangandalam pelaksanaan otonomi daerah. Pemerintah pusat bertanggungjawab menjamin keutuhan Negara kesatuan, menjamin pelayanan yang sama untuk seluruh rakyat Negara (asas equal treatment), menjamin keseragaman tindakan dan pengaturan dalam bidang-bidang tertentu (asas uniformitas). Pembatasan atas keleluasaan Daerah dalam mengatur dan mengurus urusan rumah tangganya dengan beberapa kewajiban tersebut, merupakan konsekuensi logis dianutnya prinsip Negara hukum. Pengawasan atau control tersebut meliputi juga control atas norma hukum yang ditetapkan oleh Pemerintah Daerah.
Sebagai perbandingan konsep, pengawasan administratif di Inggris terdiri dari 3 model; pertama, pengesahan byelaws, pertimbangan yang dilakukan dalam pengesahan bye-laws bukan hanya sekedar memeriksa aspek-aspek hukumnya tetapi juga memeriksa sasaran yang hendak dicapai, dan apakah tindakan itu memang diperlukan dengan pertimbangan kondisi setempat atau kepentingan nasional. Kedua, persetujuan atas rancangan atau usulan yang diajukan daerah (approval of schemes). Beberapa undang-undang menentukan, bahwa daerah yang akan melaksanakan suatu fungsi pelayanan yang diserahkan kepada mereka, diwajibkan terlebih dahulu menyampaikan rancangan atau usulan mengenai cara melaksanakan fungsi pelayanan tersebut. Rancangan, usulan atau rencana itu harus disampaikan kepada menteri untuk memperoleh persetujuan. Setelah persetujuan diperoleh, barulah fungsi pelayanan yang diserahkan tersebut dapat diselenggarakan. Ketiga, persetujuan atas tindakan-tindakan tertentu (consent for individual acts). Maksudnya adalah bahwa dalam hal-hal tertentu pemerintah daerah diperbolehkan melakukan suatu tindakan apabila telah memperoleh persetujuan pemerintah pusat (menteri).

Belanda memiliki 2 bentuk pengawasan yang rupanya banyak ditiru oleh di Negara kita. Pertama, pengawasan preventif, yakni pertimbangan atau oegawasan yang dilakukan sebelum Pemerintah Daerah mengambil suatu keputusan. Kedua, pengawasan represif, yakni pertimbangan atau pengawasan yang dilakukan setelah 
pemerintah daerah mengambil keputusan namun sebelum keputusan itu berlaku dan memiliki akibat hukum.

Di Indonesia, guide line pelaksanaan Pemerintahan Daerah diatur dalam UndangUndang Nomor 32 tahun 2004 yang kemudian dijabarkan ke dalam beberapa Peraturan Pemerintah dan Peraturan Menteri Dalam Negeri, diantaranya yakni Peraturan Menteri Dalam Negeri Nomor 53 Tahun 2007. Dalam permendagri ini disebutkan mengenai mekanisme Klarifikasi dan Evaluasi oleh Gubernur terhadap Peraturan Walikota/Bupati dan oleh Mendagri terhadap Peraturan Gubernur (Bab III bagian kesatu dan kedua). Yang perlu digarisbawahi dalam konsep pengawasan ini adalah bahwa Pengawas (Mendagri dan Gubernur) diberikan wewenang mengevaluasi namun hasil evaluasi tersebut -jika apabila berupa pembatalan- tidak bisa secara otomatis membatalkan Peraturan Kepala Daerah yang telah dibuat. Mengapa demikian? Karena asas yang digunakan dalam konsep ini adalah Asas Contrarius Actus yang berarti bahwa dalam konsep pemerintahan pihak yang berhak mencabut suatu perbuatan hukum adalah pihak yang membuatnya. Sehingga, hasil evaluasi dari Mendagri dan Gubernur berupa perintah pembatalan.

\section{Karakteristik pengujian (toetsingrecht) oleh MA.}

Mahkamah Agung sebagai lembaga yang melaksanakan Kekuasaan Kehakiman adalah merupakan Pengadilan Negara Tertinggi dari semua lingkungan peradilan, dalam melaksanakan tugasnya adalah kekuasaan yang mandiri, bebas dari pengaruh pemerintah (eksekutif), pengaruh pembuat undang-undang (legislatif) maupun pengaruh luar lainnya serta melakukan pengawasan tertinggi atas pelaksanaan peradilan sesuai dengan ketentuan UU No. 4 tahun 2004 tentang Kekuasaan Kehakiman dan UU No. 5 tahun 2004 tentang Perubahan atas UU No. 14 tahun 1985 tentang Mahkamah Agung. ${ }^{9}$ Wewenang pengujian peraturan perundang-undangan di bawah undang-undang terhadap undangundang yang dimiliki oleh Makamah Agung tersebut sering dikenal dengan istilah judicial review. Namun istilah judicial review sering dipersamakan dengan istilah toetsingsrecht, padahal diantara keduanya memiliki perbedaan. Apabila diartikan kata per kata tanpa mengkaitkannya dengan sistem hukum tertentu, Toetsingsrecht berarti hak menguji, sedangkan Judicial Review berarti peninjauan oleh lembaga pengadilan sehingga pada dasarnya, kedua istilah tersebut mengadung arti yang sama, yaitu kewenangan untuk menguji atau meninjau. Perbedaannya adalah dalam istilah judicial review sudah secara spesifik ditentukan bahwa kewenangan tersebut dimiliki oleh pelaksana lembaga pengadilan, yaitu hakim. ${ }^{10}$ Menurut Encyclopedia Britannica : Judicial review is the power of courts of a country to determine if acts of legislature and executive are constitutional. Bintan R. Saragih menyebutkan : Judicial

${ }^{9}$ Ujang Abdullah, Hak Uji Materiil di Bawah Undang-Undang, tanpa tahun, hlm. 1 diakses dari www. ptun.palembang.go.id/upload data/HUM.pdf pada tanggal 21 Oktober 2011 pukul 13.30 wib

${ }^{10}$ Fatmawati, Hak Menguji (Toetsingsrecht) yang Dimiliki Hakim dalam Sistem Hukum Indonesia, RajaGrafindo Persada, Jakarta, 2005, hlm. 4-5. 
Review ... adalah hak dari Mahkamah Agung untuk menilai atau menguji secara material apakah suatu undang-undang bertentangan dengan atau tidak berlaku undang-undang yang dinyatakan bertentangan atau tidak sesuai.$^{11}$

Penggunaan istilah hak menguji (toetsingsrecht) dan judicial review sering menimbulkan kerancuan apabila digunakan dalam bahasa Indonesia. Kekeliruan tersebut terjadi karena terdapat anggapan bahwa judical review identik dengan hak menguji (toetsingsrecht). Definisi dari judicial review terdapat pada negara common law system dan hak menguji (toetsingsrecht) terdapat pada negara civil law system, maka menurut Fatmawati ${ }^{12}$ terdapat perbedaan pada keduanya, yaitu:

1. Hak menguji (toetsingsrecht) merupakan kewenangan untuk menilai peraturan perundang-undangan terhadap UUD, sedangkan judicial review tidak hanya menilai peraturan perundang-undangan tetapi juga administrative action terhadap UUD.

2. Hak menguji (toetsingsrecht) terhadap peraturan perundang-undangan tidakhanya dimiliki oleh hakim, tapi juga oleh lembaga negara lain yang diberi kewenangan tersebut berdasarkan peraturan perundangundangan, sedangkan judicial review hanya merupakan kewenangan dari hakim pengadilan dalam kasus konkret di pengadilan.

${ }_{11}$ Tubagus Haryo Karbyanto, JUDICIAL REVIEW : Antara Trend dan Keampuhan bagi Strategi Advokasi, Lembaga Studi dan Advokasi Masyarakat (ELSAM), Jakarta, 2005, hlm. 2

${ }^{12}$ Fatmawati, Op.Cit., hlm. 11
Ketentuan menyangkut putusan diatur dalam bab IV sampai dengan bab VI Perma no. 1 Tahun 2011 tentang hak uji materiil. Berdasarkan Perma tersebut, Secara garis besar isi putusan MA dapat dibagi menjadi 2, yaitu pengabulan dan penolakan terhadap peraturan perundangan yang dimohonkan penhujiannya. Mahkamah menilai ketepatan alasan yang dijadikan landasan bagi pemohon baik secara materiil maupun dari aspek formil. Dalam hal pengajuan permohonan tersebut dikabulkan oleh MA, maka dalam putusannnya MA menyatakan bahwa peraturan perundangan yang dimohonkan tidak sah atau tidak berlaku untuk umum. Selanjutnya MA memerintahkan instansi yang bersangkutan (yang membuat peraturan perundangan) untuk mencabut peraturan perundangan yang telah dibatalkan tersebut.

Perma No.1 tahun 2011 juga menjelaskan konsekuensi terhadap suatu peraturan perundang-undangan yang telah dibatalkan oleh MA. Perma menyatakan, jika tidak ada tindakan pencabutan dari badan atau pejabat tata usaha negara dalam 90(Sembilan puluh) hari semenjak putusan pembatalan dikirimkan ke Badan atau Pejabat tata usaha Negara tersebut, peraturan perundangan yang dibatalkan demi hukum dianggap tidak lagi memiliki kekuatan hukum. Hal ini tentu saja berlaku untuk perkada. Perma No.1 tahun 2011 didesain untuk mengatasi kelemahan pada Perma sebelumnya terkait masalah daluwarsa. MA membatasi waktu pengajuan permohonan 180 hari semenjak suatu peraturan perundang-undangan disahkan. 
Hal ini lantas banyak dikeluhkan oleh berbagai pihak karena berpotensi merugikan para calon pencari keadilan sehingga terdapat pengaturan baru dalam Perma no. 1 tahun 2011.

\section{Political Review Oleh Dewan Perwakilan Rakyat Daerah}

Beberapa bagian diatas telah
menjelaskan tentang bentuk-bentuk daerah (perkada) yang ditinjau dariperspektif kekuasaan "eksekutif" (pemerintah dalam arti sempit) juga dari perspektif Kekuasaan Yudisiil. Namun, terdapat satu "cabang kekuasaan" lagi (dalamkonteks daerah) yang sebenarnya memiliki kewenangan untuk melakukan pengawasan terhadap perkada. "cabang kekuasaan" ini terepresentasikan dalam wujud Dewan Perwakilan Rakyat Daerah (DPRD), baik di tingkatan Provinsi maupun tingkatan Kabupaten atau Kota.

Selanjutnya, akan diuraikan juga mengenai Tugas, wewenang, hak dan Kewajiban DPRD. Lebih lanjut lagi, Fungsi dan bentuk-bentuk pengawasan oleh DPRD juga akan dielaborasi dengan menitik beratkan pada pengawasan DPRD terhadap perkada. Terakhir, akan diajukan analisa atas mekanisme pengawasan terhadap perkada oleh DPRD tersebut.

Indonesia merupakan negara kesatuan yang berbentuk republik. Kalimat tersebut termaktub dalam pasal 1 ayat (1) UndangUndang Dasar Negara Republik Indonesia. Dengan bentuk yang demikian, maka Indonesia tidaklah terkualifikasi dalam bentuk negara yang monarkhis, dimana terdapat Raja sebagai Kepala Negara. Pilihan bentuk negara ini tentunya bukan tanpa sebab. Dalam bentuk Republik terdapat nuansa kesetaraan (egalitarian) yang berorientasi pada rakyat. Hal ini sangat berbeda jika dibandingkan dengan bentuk negara monarki yang lebih mengedepankan faktor genetis dalam penentuan pemegang kekuasaan.

Selain itu Indonesia menahbiskan diri sebagai negara Kesatuan (unitary state). Konsekuensi dari negara kesatuan adalah tidak dimungkinkannya adanya kedaulatan laindalam suatu negara. Meskipun demikian, bukan berarti kekhasan yang dimiliki di setiap daerah menjadi hilang. Pengaturan mengenai pemerintah daerah dalam UUD 1945 telah menunjukkan bahwa terdapat penghormatan negara terhadap kekhasan yang dimiliki suatu daerah.

Pada UUD 1945 sebelum amandemen pengakuan tersebut terdapat pada pasal 18. Perihal DPRD tidak secara eksplisit di sebutkan dalam UUD 1945, namun penjelasan umum UUD 1945 tentang pemerintahan daerah disebutkan "didaerahdaerah yang bersifat otonom, akan diadakan badan perwakilan daerah oleh karena di daerah pun pemerintahan akan bersendi atas dasar permusyawaratan". Sebagai tindak lanjut atas ketentuan pada pasal 18 tersebut diatas, pada tanggal 23 November 1945 Pemerintah menyetujui UU nomor 1 Tahun 1945 tentang kedudukan komite nasional daerah. Menurut pasal 2 UU ini, Komite Nasional Daerah (KND) berubah menjadi Badan Perwakilan Rakyat Daerah 
yang memiliki tugas untuk mengatur jalannya pemerintahan di daerah bersamasama dengan Kepala Daerah ${ }^{13}$. Sebagaimana Komite Nasional Indonesia Pusat (KNIP), tugas-tugas yang dimiliki KND juga memiliki kesamaan dalam hal legislasi, yaitu membuat peraturan-peraturan untuk kepentingan daerah.

Pun demikian halnya dalam Konstitusi RepublikIndonesiaSerikat(RIS), pengaturan tentang kekhasan wilayah tertentu semakin mendapat tempat mengingat bentuk negara yang dianut adalah federalisme. Khusus untuk daerah Swapraja (otonom) diatur tersendiri di dalam ketentuan pasal 64 sampai dengan 67 Konstitusi RIS. UUDS 1950 perihal pemerintah daerah dan daerah swapraja diatur dalam bab IV pasal 131 sampai dengan 133.

Undang Undang Dasar Negara Republik Indonesia 1945 (UUD NRI 1945) pasca amandemen mengatur di dalam pasal 18 perihal pemerintahan daerah termasuk didalamnya dewan perwakilan rakyat daerah (DPRD). Pada pasal 18 ayat (3) disebutkan bahwa Pemerintahan daerah propinsi, daerah kabupaten, dan kota memiliki Dewan Perwakilan Rakyat Daerah yang anggota-anggotanya dipilih melalui pemilihan umum. Pada ayat selanjutnya (ayat 5) dijelaskan perihal Pemerintahan daerah berhak menetapkan peraturan daerah dan peraturan peraturan lain untuk melaksanakan otonomi dan tugas pembantuan. Pada ayat (7) disebutkan Susunan dan tata cara penyelenggaraan

\footnotetext{
${ }^{13}$ Mahfud M.D, Politik Hukum Di Indonesia, Jakarta:Rajawali,2009. hal. 104.
}

pemerintahan daerah diatur dalam undangundang. Makna dari pengaturan UUD NRI 1945 tersebut adalah DPRD merupakan bagian dari pemerintahan daerah yang memiliki hak untuk menetapkan peraturan daerah danperaturanperaturanlain (termasuk didalamnya peraturan kepala daerah bagi Gubernur dan Bupati/Walikota).

Pengaturan lebih lanjut mengenai kedudukan DPRD ini dituangkan dalam Undang-Undang. Setidaknya terdapat 3 Undang-Undang yang mengatur perihal kedudukan DPRD. Undang Undang pertama adalah UU tentang susunan dan kedudukan Majelis Permusyawaratan Rakyat, Dewan Perwakilan Rakyat, Dewan Perwakilan Daerah, dan Dewan Perwakilan Rakyat Daerah (UU SUSDUK MD3). Dalam UU SUSDUK MD 3 tersebut disebutkan bahwa kedudukan DPRD Provinsi merupakan lembaga perwakilan rakyat daerah yang berkedudukan sebagai lembaga pemerintahan daerah di Provinsi (vide pasal 60). Penjelasan dari pasal tersebut menyatakan bahwa DPRD Provinsi adalah bagian dari pemerintahan daerah. Sedangkan DPRD Kabupaten/Kota merupakan lembaga perwakilan rakyat daerah yang berkedudukan sebagai lembaga pemerintahan daerah kabupaten/kota (vide pasal 76) . Sama halnya dengan DPRD Provinsi, kedudukan DPRD Kabupaten/ Kota adalah juga merupakan bagian dari pemerintahan daerah Kabupaten/Kota.

Pengaturan kedua tentang DPRD adalah pada UU nomor 32 tahun 2004 tentang Pemerintahan Daerah (UU Pemda). UU Pemda menegaskan lagi apa yang sudah 
diatur dalam UU SUSDUK MD3. Bahkan dalam kaitannya dengan penyelenggaraan pemerintahan, UU Pemda memberi penjelasan yang lebih. Perihal kedudukan DPRD ini, UU Pemda mengaturnya dalam pasal 40 yang substansinya memiliki kesamaan dengan apa yang sudah diatur dalam UU SUSDUK MD3. Pasal 19 ayat (1) UUPemdapadababtentangpenyelenggaraan pemerintahan menyebutkan bahwa penyelenggara pemerintahan adalah Presiden dibantu dengan satu orang Wakil Presiden dan oleh Menteri Negara. Pada pasal duanya disebutkan penyelenggara pemerintahan daerah adalah pemerintah daerah dan DPRD. Termasuk didalam pemerintah daerah adalah Kepala daerah beserta perangkatnya. Dikaitkan dengan konsepsi negara kesatuan, maka DPRD adalah bagian dari pemerintahan daerah yang merupakan bagian dari kekuasaan eksekutif. Undang-undang ketiga adalah Undang Undang nomor 27 tahun 2009 tentang Majelis Permusyawaratan Rakyat, Dewan Perwakilan Rakyat, Dewan Perwakilan Daerah, Serta Dewan Perwakilan Rakyat Daerah (UU MD3). Kedudukan DPRD menurut UU MD3 juga setali 3 uang dengan pengaturan pada UU sebelumnya yaitu sebagai salah satu unsur penyelenggara pemerintahan di daerah (vide. Pasal 291).

DPRD merupakan bagian dari kekuasaan eksekutif yang melaksanakan fungsi-fungsi tertentu yang khas. Kekhasan ini muncul karena proses rekruitmen DPRD melalui pemilihan umum sehingga dalam beberapa hal DPRD memiliki karakteristik yang sama dengan DPR pusat, meskipun DPRD merupakan bagian dari pemerintahan daerah. Dilihat dari perspektif pemisahan kekuasaan maka DPRD merupakan bagian dari kekuasaan eksekutif. Penjelasannya adalah sebagai berikut :

Teori pemisahan kekuasaan seringkali merujuk pada teori yang diajukan oleh Baron Charles de Montesqieu yang dikemudian hari dilabeli sebagai "trias politica" oleh Immanuel Kant. Teori klasikini mendalilkan, untuk mencegah menumpuknya kekuasaan dalam suatu negara yang berakibat pada besarnya potensi penyelewengan kekuasaan maka kekuasaan itu haruslah dipisah.

Identifikasi Montesqieu membawa pada simpulan bahwa dalam suatu negara terdapat tiga fungsi yang juga harus dijalankan oleh tiga pemegang kekuasaan yang berbeda. Fungsi-fungsi tersebut terdiri dari fungsi legislatif, eksekutif, dan yudikatif. Fungsi legislatif adalah fungsi pembuat undangundang, fungsi eksekutif merupakan fungsi pelaksana undang undang, serta fungsi yudikatif yang memutuskan perkara yang timbul akibat pelaksanaan kekuasaan ${ }^{14}$. Teori ini lantas berkembang dan banyak diadopsi oleh berbagai negara dengan berbagai modifikasi.

Dalam Konteks Indonesia, konsep Trias Politica mewujud dengan modifikasi yang berbeda dengan konsep asalinya. Tidak ada pemisahan yang benar-benar tegas antar lembaga pelaksana kekuasaan, melainkan mereka berbagi kekuasaan antara satu

${ }^{14}$ Franz Magnis Suseno, Etika Politik: Prinsip-prinsip Moral dasar Kenegaraan Modern, (Jakarta:Gramedia 1988) Hal. 225 
dengan lainnya. Sebagai contoh, Presiden yang selama ini merupakan representasi kekuasaan eksekutif pada kenyataannya juga memiliki kewenangan yang beririsan dengan Dewan Perwakilan Rakyat dalam hal membentuk Undang-Undang. ${ }^{15}$ Demikian halnya dalam hal pemberian grasi dan rehabilitasi, Presiden memiliki kewenangan masalah itu, meskipun sejatinya kewenangan itu ada pada ranah kekuasaan Yudikatif. ${ }^{16}$ Karena itulah maka bentuk pemisahan (pemencaran) kekuasaan di Indonesia didasarkan atas semangat perimbangan serta kekuasaan yang saling mengawasi diantara pelaku kekuasaan.

Perimbangan kekuasaan yang ada di pusat juga berlaku di daerah, meskipun pemerintahan yang di daerah adalah bagian dari kekuasaan eksekutif. Sebagaimana telah dikemukakan pada bagian sebelumnya, pemerintahan di daerah terdiri dari Kepala Daerah beserta perangkatnya dengan DPRD. Ketiganya merupakan kesatuan pemerintahan di daerah. Meskipun ketiganya merupakan suatu kesatuan, bukan berarti mereka memiliki kesamaan fungsi. Pemerintah Daerah lebih menekankan pada pelaksanaan pemerintahan seharihari sedangkan DPRD berfungsi sebagai pengawas dari jalannya pemerintahan yang dilakukan oleh Pemerintah Daerah.

Dari beberapa hal tersebut diatas, bisa kita cermati bahwa konsepsi tentang pemisahan kekuasaan tidak hanya terjadi antar cabang kekuasaan, melainkan di internal satu cabang kekuasaan juga

\footnotetext{
15 Pasal 5 jo. Pasal 20 UUD NRI 1945.

${ }^{16}$ Pasal 14 ayat (1) UUD NRI 1945.
}

terdapat pola yang demikian. Sebagai salah satu penyelenggara pemerintahan, DPRD memiliki Fungsi yang berbeda dengan Kepala Daerah. Fungsi DPRD secara umum seperti yang diatur dalam peraturan perundang-undangan baik UU SUSDUK MD3, UU MD3 maupun UU Pemda adalah :Fungsi legislasi, Fungsi Anggaran, serta Fungsi Pengawasan. Kesemua fungsi yang dimiliki oleh DPRD tersebut merupakan derivasi dari fungsi representasi DPRD yang mendapatkan legitimasinya melalui proses politik (pemilihan umum).

Dalam melakukan fungsi yang melekat pada dirinya, DPRD memiliki seperangkat hak guna mendukung fungsi tersebut. Sebagaimana dalam hal tugas dan wewenang, maka UU SUSDUK MD3 juga membedakan hak dan kewajiban yang dimiliki DPRD Provinsi dan DPRD Kota/ Kabupaten. UU SUSDUK MD3 mengatur bahwa DPRD Provinsi mempunyai hak seperti yang diatur dalam pasal 63 meliputi : Hak interpelasi, Hak angket, Hak menyatakan pendapat.

Dalam melakukan tugas dan wewenangnya anggota DPRD juga memiliki hak untuk meminta keterangan dari pihak manapun yang berkaitan dengan kepentingan daerah, bangsa dan negara. Hal berkait dengan hak dari DPRD Provinsi diatas juga berlaku secara mutatis mutandis terhadap DPRD Kabupaten atau Kota. Dan kalau diperhatikan hak-hak yang ada pada DPRD Provinsi maupun Kabupaten/Kota analog dengan hak yang dimiliki oleh DPR yang ada di pusat. 
Bentuk-bentuk pengawasan yang dilakukan oleh DPRD secara eksplisit telah dinyatakan, yaitu dalam UU SUSDUK MD3 pasal 61-62 terkait dengan DPRD Provinsi serta pada pasal 77-78 jika terkait dengan DPRD Kabupaten/Kota. UU Pemda mengatur secara lebih ringkas pada pasal 41-42 karena tidak dibedakan antara DPRD Provinsi dengan DPRD Kabupaten/Kota. Pada pasal 61, 77 UU SUSDUK MD3 serta pasal 41 UU Pemda disebutkan bahwa salah satu fungsi yang dimiliki DPRD (Provinsi/Kabupaten/Kota) adalah fungsi pengawasan. Hal yang hampir sama juga dapat dibaca pada pasal 292 dan 293 UU MD3. Penjabaran atas fungsi pengawasan ini terdapat pada pasal sesudahnya yang mengatur tentang tugas dan kewenangan DPRD. Pengawasan terhadap perda dan peraturan perundang-undangan lain, Pengawasan terhadap keputusan Kepala Daerah, Pengawasan terhadap APBD, Pengawasan terhadap Kebijakan Pemerintah Daerah, Kerjasama Internasional di daerah.

Mekanisme pengawasan peraturan Kepala Daerah oleh DPRD Telah dijelaskan diawal bahwa UU (baik MD3 maupun UU Pemda) tidak memberikan penjelasan yang lebih rinci terkait mekanisme pengawasan yang dilakukan DPRD terhadap Perkada yang telah dibuat. Ketentuan dalam UU Pemda dan UU SUSDUK MD3 hanya menyebutkan DPRD memiliki wewenang untuk melaksanakan pengawasan terhadap pelaksanaan peraturan daerah dan peraturan perundang-undangan lainnya, keputusan bupati/walikota, APBD, kebijakan pemerintah daerah dalam melaksanakan program pembangunan daerah, dan kerjasama internasional di daerah. Dalam ketentuan tersebut, nomenklatur Perkada termasuk dalam frase "peraturan perundangundangan lainnya". Dengan demikian, kewenangan pengawasan terhadap Perkada tidak dilengkapi dengan instrument penegakannya yang tentu saja berimbas pada efektifitas keberlakuannya. Pertanyaan selanjutnya, jika batasan serta mekanisme pengawasan terhadap Perkada tidak diatur, bagaimanabentuk pengawasannya?Terlebih jika substansi Perkada bertentangan dengan Perda yang dijadikan landasan perbuatan Perkada.

Karena terkait dengan norma kewenangan, maka sesuatu yang tidak diatur belum tentu berarti boleh dilaksanakan. Esensi dari norma kewenangan adalah gagasan pembatasan kekuasaan supaya tidak digunakan secara sewenang-wenang. Hal ini juga berlaku dalam kaitan pengawasan terhadap Perkada oleh DPRD. Misalnya, ketiadaan perincian pengaturan mengenai mekanisme pengawasan terhadap Perkada oleh DPRD tidak menjadikan DPRD memiliki kewenangan untuk membatalkan Perkada, meskipun secara substansial Perkada tersebut dianggap bertentangan dengan Perda.

Akan tetapi ketiadaan pengaturan itu tidak berarti jalan untuk melakukan pengawasan menjadi tertutup bagi DPRD. Pada awal penelitian telah dibahas sekilas mengenai fungsi dan hak yang dimiliki oleh DPRD. Salah satu fungsi DPRD adalah pengawasan. Untuk mendukung fungsi 
pengawasan ini, terdapat hak-hak yang melekat pada DPRD. Hak-hak tersebut adalah hak menyatakan pendapat, Hak Interpelasi dan Hak angket seperti yang sudah dikemukakan di awal. Dalam rangka pengawasan terhadap Perkada, hak-hak ini dapat juga digunakan karena perkada merupakan salah satu bentuk kebijakan yang dikeluarkan oleh Kepala daerah dimana keberadaannya berdampak pada masyarakat luas.

Dari ketiga hak tersebut, yang paling signifikan untuk dijadikan instrumen pengawasan adalah hak angket. Hak angket adalah hak untuk melakukan penyelidikan terhadap kebijakan Kepala Daerah yang penting dan strategis serta berdampak luas pada kehidupan masyarakat, daerah dan negara yang diduga bertentangan dengan peraturan perundang-undangan. Yang dimaksud bertentangan dengan peraturan perundang-undangan adalah peraturan perundang-undangan yang lebih tinggi.

Undang-Undang Nomor 12 tahun 2011 tentang pembentukan peraturan perundangundangan (UU P3) mengatur perihal tata urutan perundang-undangan dalam pasal 7 dan pasal 8. Dalam stelsel Undang-Undang Nomor 12 Tahun 2011 LN Tahun 2011 No. 82, TLN 5234, perkada terkualifikasi dalam pengertian peraturan perundang-undangan pada pasal 8 ayat (1). Sedangkan pengakuan eksistensinya diatur dalam ayat (2). Pengakuan terhadap tersebut mensyaratkan 2 hal yaitu sepanjang diperintahkan oleh peraturan perundang-undangan yang lebih tinggi dan berdasarkan kewenangan. Lazimnya, Perkada dibuat sebagai aturan pelaksana dari perda yang telah dibuat. Dengan pengertian tersebut maka kedudukan Perda lebih tinggi daripada Perkada. Sebagai konsekuensi logis atas hal tersebut maka substansi yang ada pada Perkada yang berasal dari perintah Perda tidak boleh bertentangan dengan Perda yang menjadi dasar pembentuknya. Untuk Perkada yang dibuat berdasarkan kewenangan haruslah dilihat dalam konteks kewenangan yang dimiliki oleh Kepala Daerah. Dengan kata lain, apakah Kepala Daerah memang dilekati kewenangan untuk membuat Perkada tersebut, meskipun tidak diperintahkan oleh peraturan perundangundangan yang lebih tinggi. Lingkup hak angket meliputi 2 jenis Perkada tersebut yaitu baik yang diperintahkan oleh Perda maupun yang dibuat berdasarkan kewenangan.

Kesimpulan ini didasarkan atas prasyarat dalam pengajuan hak angket memuat ketentuan jika suatu kebijakan Kepala Daerah (termasuk Perkada) diduga "bertentangan dengan peraturan perundang-undangan". Didalam UU P3 disebutkan mengenai asas kelembagaan dan pejabat pembentuk yang tepat (vide Pasal 5) dimana didalamnya terkandung makna bahwa peraturan perundangan yang dibuat hendaklah sesuai dengan kewenangan yang dimiliki lembaga maupun pejabat yang membentuknya, sehingga jika terdapat penyalahgunaan wewenang dalam pembuatan Perkada(yang tidak diperintahkan peraturan perundangan lain tetapi dibuat berdasarkan wewenang yang ada pada Kepala Daerah) tetap dianggap bertentangan dengan peraturan perundang- 
undangan.Muara dari hak angket ini bisa membawa pada pemberhentian Kepala Daerah. (lihat bagan)

Untuk mendukung hak angket tersebut, maka DPRD dibekali dengan kewenangan untuk memanggil siapapun baik pejabat Negara, badan hukum, atau warga masyarakat demi memberi keterangan yang diperlukan dalam penyelidikan. Jika terdapat penolakan dari pihak-pihak tersebut tanpa ada alasan yang sah menurut hukum maka pihak-pihak tersebut dapat dihadirkan secara paksa (vide pasal 66 UU susduk MD3; pasal 17 UU MD3). Ketentuan dalam pasal ini sekaligus membuka ruang partisipasi bagi setiap unsur dalam masyarakat untuk memberikan keterangan seoptimal mungkin terkait dengan kebijakan Kepala Daerah yang menjadi objek pengawasan DPRD. Secara garis besar dapat disimpulkan bahwa DPRD memiliki kewenangan untuk mengawasi Perkada. Namun kewenangan tersebut tidak dilengkapi dengan instrument penegakan yang langsung tertuju pada Perkada itu sendiri. Hal ini menyebabkan pengawasan terhadap Perkada tidak dapat berjalan dengan efektif. Tidak terdapat kewenangan DPRD untuk membatalkan suatu Perkada. Padahal, Perkada yang dibuat mestinya mengacu pada Perda karena lazimnya Perkada dibuat karena adanya perintah dari Perda. Meskipun demikian, DPRD memiliki mekanisme pengawasan yang dapat diterapkan pada Perkada.

Dalam mekanisme pengawasan terhadap Perkada tersebut, DPRD dapat melibatkan dan membuka ruang partisipasi bagi masyarakat luas untuk bisa memberikan masukan, keterangan perihal kebijakan yang dipermasalahkan. Masyarakat bisa juga langsung memberi masukan kepada pemerintah daerah dengan difasilitasi oleh DPRD. DPRD dapat memanggil siapapun untuk memberikan keterangan bahkan Kepala Daerah itu sendiri.

Sebagai saran lanjut atas penelitian ini, diperlukan pengaturan lebih detail lagi mengenai mekanisme pengaeasan Perkada oleh DPRD. Didalam pengaturan tersebut seyogyanya memuat mekanisme evaluasi DPRD terhadap rancangan Perkada yang dibuat oleh Kepala Daerah. Secara teknis, sebelum rancangan Perkada yang dibuat oleh pihak Pemerintah disahkan atau ditetapkan Kepala Daerah, seharusnya draft dari rancangan tersebut dikirim ke DPRD terlebih dahulu untuk ditinjau dan dilihat apakah pengaturan yang ada pada Perkada tersebut sesuai dengan substansi Perda yang memerintahkannya atau tidak, atau setidaknya tidak bertentangan dengan peraturan perundang-undangan yang lebih tinggi. Dengan demikian, harmonisasi hukum dapat terjadi dan potensi konflik antara DPRD dengan Kepala Daerah bisa dihindari dimasa yang akan datang. 


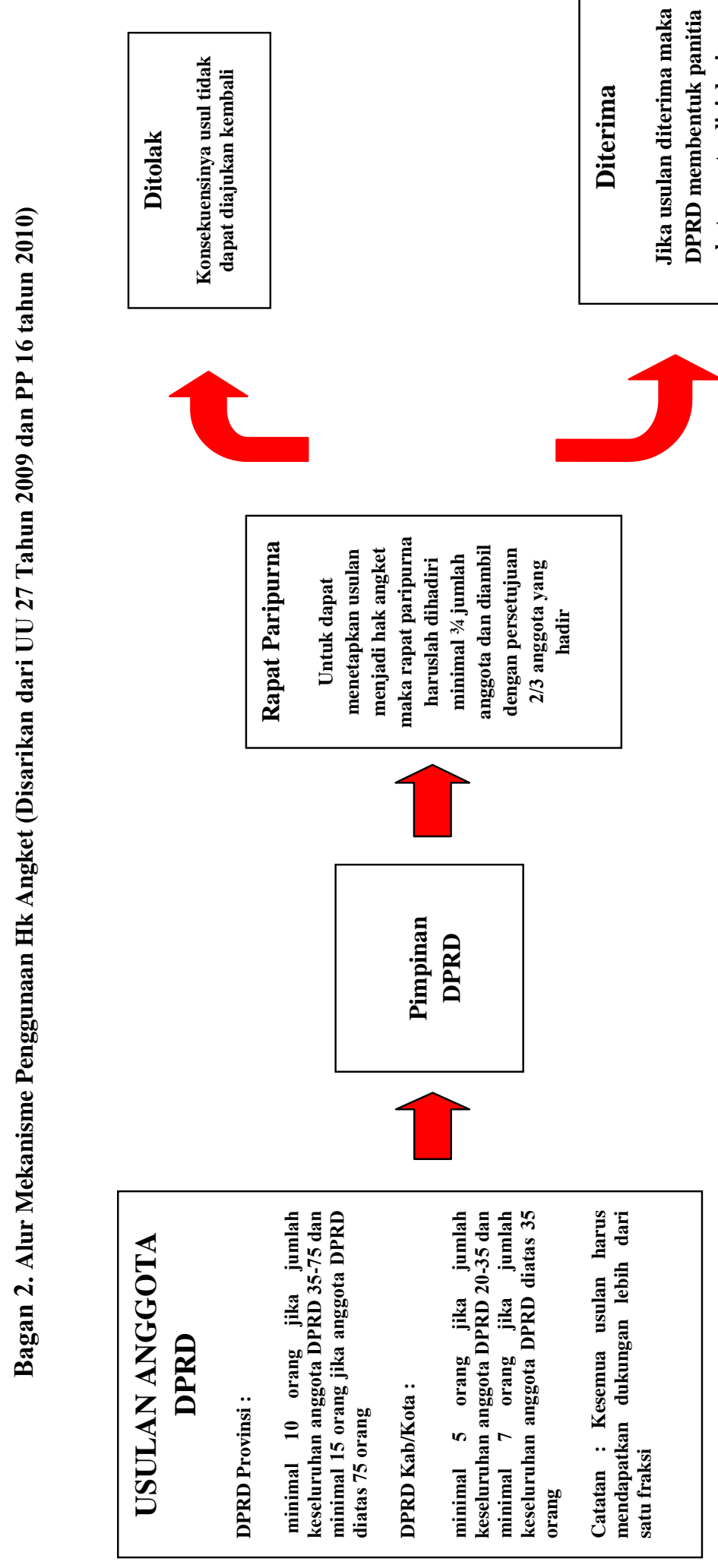




\section{Kesimpulan}

Dari paparan dan pembahasan diatas, dapat disimpulkan bahwa peraturan kepala daerah merupakan bagian peraturan perundang-undangan yang berisi materi sebagaimana yang dimanatkan oleh peraturan daerah. Selain itu sumber wewenang pembuatan perkada juga berasal dari kewenangan diskresi dalam rangka pelaksanaan pemerintahan daerah.

Pengawasan terhadap perkada dapat dilakukan melalui mekanisme

1) Executive Review; Pengawasan yang dilakukan oleh pemegang kewenangan yang lebih tinggi. Dalam hal ini melalu Gubernur untuk Perkada Bupati/Walikota, atau Mendagri jika Perkada tersebut dibuat oleh Gubernur. Mekanisme ini menunjukkan bahwa "Kekuasaan yang dibagi dalam konteks Otonomi adalah kekuasaan eksekutif”, maka otonomi harus dilaksanakan secara nyata dan bertanggung jawab dalam bingkai Negara Kesatuan.

2) Judicial Review; Berbeda dengan model executive review, pengawasan yang dilakukan MA ini bersifat pasif dan memerlukan "trigger" berupa kerugian materiil yang ditimbulkan oleh diberlakukannya Perkada.

3) Political Review: DPRD sebagai lembaga politik (bukan legislative) yang memiliki legitimasi kekuasaan yang setara dengan Kepala Daerah (dimana keduanya dipilih rakyat melalui Pilkada Langsung), maka DPRD dapat mengambil posisi sebagai penyeimbang roda Pemerintahan di daerah melalui Tupoksi yang diberikan oleh peraturan perundang-undangan.

Paradigma yang dibangun dalam pembentukan produk hukum daerah seyogyanya berorientasi pada Legal Reform dan lebih memprioritaskan pada tindakan nyata/materiil daripada tindakan hukum. Dalam merespon masalah sosial, sering kali Pemerintah Daerah menganggap pembentukan aturan sebagai solusinya, padahal pada prinsipnya tidak semua permasalahan sosial dapat diselesaikan dengan Peraturan Perundang-undangan. Banyaknya produk hukum daerah acapkali justru mengancam upaya sinkronisasi peraturan perundang-undangan untuk mencapai suatu "order" dalam tatanan Sistem Peraturan Perundang-undangan di Indonesia.

Walaupun demikian, tidak berarti pembentukan produk hukum daerah bisa dihentikan. Bagaimanapun produk hukum daerah termasuk Perkada adalah refleksi dari dinamika otonomi daerah, maka jikapun harus dibuat peraturan, Pemerintah Daerah harus memastikan bahwa produk hukum tersebut memenuhi

(1) Asas-Asas Pembentukan Peraturan Perundang-undangan yang baik

(2) Asas Kemanfaatan

(3) Kesesuaian nomenklatur dengan materi muatan 
(4) Khusus untuk Perkada maka muatannya haruslah hanya hal-hal yang bersifat administratif dan rinci sehingga setiap normanya jelas, serta sebisa mungkin tidak mendelegasikan ke peraturan yang lebih teknis lagi.

\section{DAFTAR BACAAN}

Asshiddiqie, Jimly, Perihal Undangundang, Rajawali Pers, Jakarta, 2010

Bahan Tayangan Materi Sosialisasi UUD NRI 1945, Sekretariat Jenderal MPR RI, 2009.

Hoesein, Zainal Arifin, Judicial Review di Mahkamah Agung RI Tiga Dekade Pengujian Peraturan Perundangundangan, Rajawali Pers, Jakarta 2009.

Fatmawati, Hak Menguji (Toetsingsrecht) yang Dimiliki Hakim dalam Sistem Hukum Indonesia, RajaGrafindo Persada, Jakarta, 2005

Indrati, Maria Farida, Ilmu Perundangundangan 1, Yogyakarta, Kanisius, 2007.

Kelsen, Hans, General Theory of Law and State, New York, Russell \& Russell, 1945.

Marzuki, Peter Mahmud, Penelitian Hukum, Kencana, Jakarta, 2009

M.D, Mahfud, Politik Hukum Di Indonesia, (Jakarta:Rajawali,2009

Ridwan, Tiga Dimensi Hukum Administrasi dan Peradilan Administrasi, FH UII Press, Yogyakarta, 2009.

Sir William Wade and Christopher Forsyth, Administrative Law, eighth edition, Oxford university Press, New York, 2000
Suseno, FranzMagnis, Etika Politik: Prinsipprinsip Moral dasar Kenegaraan Modern, Jakarta:Gramedia 1988

Yuliandri, Asas-asas Pembentukan Peraturan Perundang-undangan yang Baik: Gagasan pembentukan Undangundang berkelanjutan, Jakarta, PT. Raja Grafindo Persada, 2009.

Wasistiono, Prof. DR. Sadu M.S, Meningkatkan Kinerja Dewan Perwakilan Rakyat Daerah, Bandung:Fokusmedia:2009

\section{Peraturan Perundang-undangan:}

UUD NRI 1945

Undang-undang Nomor 10 Tahun 2004 tentang Pembentukan Peraturan Perundang-Undangan

Undang Undang Nomor 12 Tahun 2011 tentang Pembentukan Peraturan Perundang-Undangan

Undang-Undang Nomor 32 Tahun 2004 tentang Pemerintahan Daerah

Undang-Undang Nomor 22 tahun 2003 tentang Susunan dan Kedudukan MPR,

DPR, DPD, DPRD

Undang Undang Nomor 27 tahun 2009 tentang MPR, DPR, DPD, DPRD

Peraturan Pemerintah Nomor 16 Tahun 2010 Pedoman Rancangan Tata Tertib DPRD

Peraturan Menteri Dalam Negeri Nomor 53 Tahun 2007 Tentang Pengawasan Perda Dan Perkada 


\section{Daftar Artikel Ilmiah:}

Adams, Wahiddudin. 2010. Peta Permasalahan Dalam Pembentukan Peraturan Daerah Dan Upaya Fasilitasi Perancangan Peraturan Daerah, djpp.depkumham.go.id., Februari, 2010

Wiratraman, R. Herlambang Perdana. 2008. "Otonomi Daerah dan Hak Partisipasi Publik dalam Pembentukan Peraturan Perundang-undangan", Jurnal Konstitusi, LKK Universitas Airlangga, Vol. I, No. 1, November 2008.

Soleh, Denden Imaduddin, 2010, Kedudukan Peraturan Kepala Daerah/Keputusan Kepala Daerah(Gubernur,Bupati,Dan Walikota) Dalam Sistem Hukum Negara Indonesia, April 2010.

\section{Laman :}

Ujang Abdullah, Hak Uji Materiil di Bawah Undang-Undang, tanpa tahun, hlm. 1 diakses dari www.ptun.palembang.go.id/ upload_data/HUM.pdf

Berita diakses di Tempointeraktif.com pada 1 Februari 2011.

Yuhardin, Gubernur Bisa Cabut Kebijakan Bupati-Walikota, http://www. scriptintermedia.com/, diakses tgl 10 Pebruari 2011 